\title{
The Capability of BPBD to Reducing Disaster Risk in Padang City - Indonesia
}

\author{
Zikri Alhadi, Bustari Muchtar, Afriva Khaidir, Eko S.V. Turnip, Novia Sari Yanti
}

\begin{abstract}
This research has the aim to describe the organizational capabilities of the Local Disaster Management Agency (BPBD) Padang in efforts to reduce disaster risk in Padang City. This study uses qualitative research methods with a descriptive approach. Data was collected through interviews with informants, field observations and documentation studies. This research was conducted at the BPBD Padang office. While the research informants were determined using purposive sampling techniques. The results of this study indicate that the capability of BPBD Padang is still not optimal. This can be seen from the problems encountered in the field, such as the coordination function carried out by the BPBD Padang, which is very weak, the lack of human resources, facilities and infrastructure that are inadequate and the budget is still very minimal.
\end{abstract}

Keywords: Capability, Disaster, BPBD, Risk, Padang.

\section{INTRODUCTION}

$T_{\text {h }}$ he world is increasingly exposed to impacts from hazards such as floods, heatwaves, drought, earthquakes and landslides [1-3]. And the Padang City is one of the regions in Indonesia which has a high level of vulnerability to disasters. Padang City is the largest city on the west coast of the island of Sumatra as well as the capital of West Sumatra Province.

Based on data from the Central Statistics Agency (BPS) in 2017 , this city has a population of 927,168 people. Potential disasters that can occur in Padang City include earthquakes, tsunamis, droughts, floods, landslides, extreme waves, coastal abrasion, land or forest fires, and so forth. These disasters have adverse impacts that cause casualties, environmental damage, property losses, and psychological impacts which in certain circumstances can hamper local development.

The government should be responsible for carrying out disaster management as regulated in Law Number 24 of 2007 concerning Disaster Management. The law stipulates that those responsible for carrying out disaster management

Revised Manuscript Received on April 30, 2020.

* Correspondence Author

Zikri Alhadi*, Department of Public Administration /Environmental and Development Studies, Universitas Negeri Padang, Padang, Indonesia. Email: zikrialhadi@fis.unp.ac.id

Bustari Muchtar, Environmental and Development Studies, Faculty of Economic, Universitas Negeri Padang, Padang, Indonesia. Email: bustarimuchtar@yahoo.com

Afriva Khaidir, Department of Public Administration, Universitas Negeri Padang, Padang, Indonesia. Email: afrivakhaidir@fis.unp.ac.id

Eko S.V. Turnip, Department of Public Administration, Universitas Negeri Padang, Padang, Indonesia. Email: ekoturnip@gmail.com

Novia Sari Yanti, Department of Public Administration, Universitas Negeri Padang, Padang, Indonesia. Email: noviayanti@yahoo.com

(C) The Authors. Published by Blue Eyes Intelligence Engineering and Sciences Publication (BEIESP). This is an open access article under the CC BY-NC-ND license (http://creativecommons.org/licenses/by-nc-nd/4.0/) are the central government and local governments through non-departmental government institutions, i.e National Disaster Management Agency (BNPB) for the central level and BPBD for the local level. With the existence of BPBD, it is expected that natural disasters occurring in the regions will be responsive to the possibility of natural disasters. The role of government in disaster risk reduction is interpreted as effective integration of disaster risk reduction considerations into sustainable development policies, plans, and programs at all levels [5]. The disaster risk reduction approach strives for reducing disaster risk through systematic and comprehensive efforts to address the causal factors of disasters [6, 7].

According to [8] organizational capability is a collection of resources that display tasks or activities integrally. Usually, the organizational capability is determined based on two approaches, i.e a) functional approach; and b) value chain approach. Both approaches are widely used by organizations to shape organizational capabilities. However, what needs to be underlined is that capabilities can only be formed if there is a collaboration between various resources within the organization. In complex organizations, capabilities affect the organizational hierarchy structure. The higher the capability level, the more integration between capabilities the lower level. Therefore, in this case, it is very necessary to integrate the functional capabilities in the organization.

[9] also said that there are four interrelated dimensions to support organizational capabilities. First, the dimensions of knowledge and skills. This dimension is the dimension most often associated with capabilities following organizational development. Second, the knowledge and skills inherent in the technical system. Third, the process of knowledge creation and control is guided by the managerial system. The fourth dimension is represented by values and norms relating to various types of knowledge that are manifested and attached to the process of creating and controlling knowledge.

\section{RESEARCH METHODS}

In this study, researchers used a type of qualitative research with descriptive methods. [10] says that qualitative research is research that aims to understand phenomena about what is experienced by research subjects holistically and using description in the form of words and language, in a special natural context and by utilizing various methods scientific. In selecting informants, researchers used a purposive sampling technique, i.e the selection of informants carried out deliberately. The informants interviewed were BPBD Padang employees and several NGOs working in the field of disaster risk reduction.

Published By:

Blue Eyes Intelligence Engineering \&

Sciences Publication

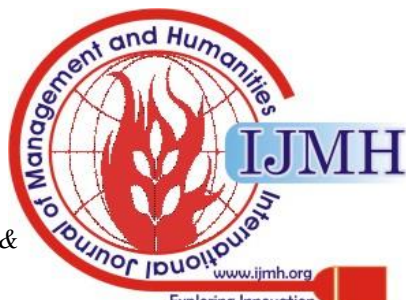




\section{The Capability of BPBD to Reducing Disaster Risk in Padang City - Indonesia}

In testing the validity of the data, researchers used source triangulation techniques used by comparing the data obtained in the study.

\section{RESULT}

[10] in [11] provides an understanding that capabilities do not represent just one resource, without designation on other resources, such as financial assets, technology or labour, but rather are a unique and superior way of allocating resources. Furthermore [11] also said that the resources and important factors that must be owned by the government to create a well-capable organization. First, institutions in which effective institutional arrangements must have clear organizational structures, roles, tasks and responsibilities and be able to establish networking with all levels of government. Second, the human resources of the organization must be sufficiently accompanied by a clear division of work and delegation, as well as having personnel with good knowledge about disaster management. Third, the organization's finances must be sufficient to support all activities in disaster management. Fourth, technical aspects in which organizations must have effective logistics management and information technology system to be able to communicate and network with various stakeholders. In this study, researchers used the theory put forward by [12] to describe the capabilities of the BPBD Padang in disaster risk reduction in Padang City.

\section{A. Institution}

The intended institution is a rule in an organization or community group to help its members to interact with each other to achieve the desired goals. As for the BPBD Padang institution, it consists of the Implementing Head, the Implementing Element Secretariat, the Prevention and Preparedness Section or Section, the Emergency and Logistics Division or Section, the Rehabilitation and Reconstruction Section or Section. Institutionalization can be seen from the formal and informal sides. Formally, the BNPB is a focal point of government agencies at the central level. Meanwhile, the focal point for disaster management at the provincial and district/city level is the BPBD.

In terms of organizational structure, BPBD Padang is good enough. This can be seen in the clear division of tasks, roles and responsibilities in the BPBD Padang. Furthermore, in carrying out its duties and functions at all stages of disaster management, BPBD Padang works based on disaster regulations such as the Head of BNPB Regulation, Minister of Internal Affairs Regulation, Local Regulation, Mayor Regulation and other laws and regulations.

But there are still important rules that are not legal in Padang City, i.e Disaster Management Plan (RPB). This RPB will be the basis for programs and activities that will be carried out by stakeholders involved in disaster management including BPBD Padang. Because the RPB is not yet legal, the programs and activities designed by the stakeholders are not integrated. For this reason, the RPB needs to have legality so that it becomes a reference for all stakeholders related to the disaster in carrying out its programs and activities.

Besides that in carrying out disaster management at the local level, BPBD Padang is assisted by various stakeholders ranging from the community itself, community organizations, to the private sector that participates in disaster management. BPBD Padang as the body in charge of disaster management must coordinate all actors in carrying out disaster management. But in practice in the field, BPBD Padang is still weak in carrying out the coordination function of all stakeholders involved in disaster management. One of the causes of the weak coordination carried out by the BPBD Padang is the sectoral ego possessed by disaster organizations in Padang City. Disaster organizations have a desire to show their existence by showing the public that is more than others. So when disasters occur, they to move on their own without direction from the BPBD Padang. This certainly makes BPBD Padang difficult in handling disasters in the field.

\section{B. Human Resources}

Human resources are one important aspect of seeing the capabilities of an organization. In line with the opinion of [13] which means that ability is a capacity that is owned by each individual to carry out their duties. The progress of an organization is largely determined by the ability of its human resources. The human resources currently owned by BPBD Padang consist of State Civil Apparatus (ASN), contract workers, and volunteer workers. Even the number of civil servants currently owned by BPBD Padang can be seen in the following Table-I below:

\section{Table-I: Number of ASN-BPBD Padang by Education} Level

\begin{tabular}{ccc}
\hline No & Education & Amount \\
\hline 1 & Doctoral Degree & 2 \\
2 & Magister Degree & 5 \\
3 & Bachelor Degree & 15 \\
4 & Diploma Degree & 3 \\
5 & Senior High School & 17 \\
\hline & TOTAL & 42 \\
\hline
\end{tabular}

Source [12]

From this table, it can be seen that the number of apparatus owned by BPBD Padang is 42 people. This number is still insufficient when compared to the number of apparatus that should be owned by the BPBD Padang, i.e 99 people following the Job Analysis Results, Workload Analysis and Competency Standards for the BPBD Padang in 2018. The shortage of personnel resulted in many positions or positions that are still vacant in BPBD Padang. To meet the lack of personnel, the BPBD Padang uses contract workers and volunteers to help carry out the duties and functions itself. The lack of personnel also caused BPBD Padang to become overwhelmed during disaster emergency response operations so BPBD Padang personnel who were supposed to work indoors had to participate in assisting the implementation of tasks in the field. BPBD Padang itself has proposed increasing the number of personnel to the central government but due to the limited state budget for disasters, the proposed addition of personnel was still not fulfilled.

In the BPBD Padang, mutations often occur that are not on time. Ideally, new ASN can be transferred within 5 years, but the fact that occurs in BPBD Padang is that ASNs that are transferred are only 1 to 2 years of work, some even within a matter of months.

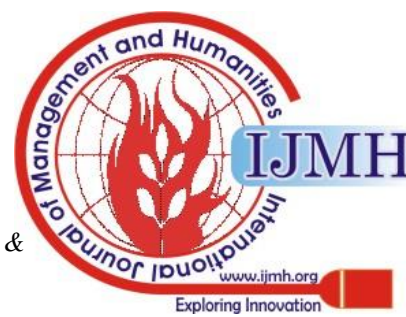


This mutation also often occurs at the level of middle officials and heads of fields so that when there are officials who want to occupy a position, he must start from the beginning again to understand the duties and functions of the position he will hold. Besides, employees who were transferred from other agencies to BPBD Padang were also not expected to work in the BPBD Padang. This is because the employee who was transferred did not have sufficient competence in disaster management so it needed a long process for employees to understand the tasks in BPBD Kota Padang. In addition, the BPBD Padang also rarely carries out activities related to training or overall capacity building for employees so that knowledge and understanding of disasters do not develop.

\section{Financial}

Finance is needed by an organization to facilitate every operation of the organization. Finance has an important role in the process of achieving a goal to be achieved by an organization. Disaster management funds are a joint responsibility between the government and local governments in which the government and local governments also encourage community participation in it as referred to in Article 60 No. 1 and 2 of Law 24 of 2007. Following the Regulations Government No. 22 of 2008 concerning Funding and Management of Disaster Assistance articles 4 and article 5 explains that the source of funds owned by the BPBD Padang comes from the State Budget (APBN), Local Budget (APBD), and the community. Besides, the government also provides funds in the form of disaster contingency funds, ready-to-use funds, and grant-funded social assistance funds.

BPBD Padang itself is still constrained about its finances. The current budget of the BPBD Padang is relatively minimal and insufficient. This is because the government still has not prioritized the issue of disaster, especially in the effort to reduce disaster risk as a strategic issue. Even in the past 2 years, the budget for BNPB and BPBD has always been cut by the government. In contrast to other countries such as Japan and the Philippines which do have fantastic funds as a form of the seriousness of their government to deal with disasters that often occur in the country.

The minimal budget for disaster also affects other aspects of the BPBD Padang such as human resources and technical aspects. In the aspect of human resources, the minimum budget resulted in the number of personnel expected to be able to join the BPBD Padang not being fulfilled due to the limited budget to pay employees. While on the technical aspect, the budget is minimal, resulting in not all of the facilities and infrastructure proposed by the BPBD Padang to the central and local governments being fulfilled. Besides, the lack of budget also impedes the implementation of programs and activities to be carried out by the BPBD Padang so that the BPBD Padang must prioritize which programs and activities are most urgent to be implemented.

BPBD Padang also received assistance in the form of Corporate Social Responsibility (CSR) from companies around the BPBD Padang. Assistance provided by these companies to the BPBD Padang is usually in the form of goods and not cash. When cash is received by the BPBD Padang can get entangled in violations in the budgeting report. Unlike when goods are received, the process is easier because the goods can be directly recorded as state assets.
Another problem that occurs is that the financial system used by the BPBD Padang in disaster risk reduction in the financial system under normal conditions while disasters are special conditions. For example, in 3 days there will be extreme weather in the Padang City while the budget budgeted by the BPBD Padang to deal with such extreme weather does not exist. That is because, in the normal financial system, the budget must first be budgeted in the previous year to be used the following year. For this reason, cooperation from the central government is needed in the effort to form a special financial system that can facilitate disaster-related institutions including the BPBD Padang.

\section{Technical}

As an organization engaged in disaster management, BPBD Padang is required to have adequate logistics management and information technology system to support the implementation of the tasks owned by the BPBD Padang. Besides, information technology systems and communication networks between organizations, the public and media representatives must also be adequate. At present, BPBD Padang still lacks adequate facilities and infrastructure. The type of equipment owned by the BPBD Padang is also incomplete and the number is still lacking. The equipment owned by the BPBD Padang can be seen in the following Table-II below:

Tabel-II: List of Equipment Owned by BPBD Padang in 2019

\begin{tabular}{|c|c|c|c|c|}
\hline \multirow[b]{2}{*}{ Equipment Type } & \multirow[b]{2}{*}{ Quantity } & \multicolumn{3}{|c|}{ Existing Conditions } \\
\hline & & $\begin{array}{c}\text { Prime } \\
\text { Condition }\end{array}$ & $\begin{array}{c}\text { Damaged } \\
\text { lightly }\end{array}$ & $\begin{array}{c}\text { Severely } \\
\text { Damaged }\end{array}$ \\
\hline Mini Bus Rescue & 1 Unit & $\sqrt{ }$ & & \\
\hline Pick Up Car & 5 Unit & $\sqrt{ }$ & & \\
\hline Multipurpose Truck & 1 Unit & $\sqrt{ }$ & & \\
\hline Double Cabin Truck & 1 Unit & $\sqrt{ }$ & & \\
\hline Mini Bus & 1 Unit & $\sqrt{ }$ & & \\
\hline Motorcycle & 13 Unit & $\sqrt{ }$ & & \\
\hline Inflatable Boat & 4 Unit & $\sqrt{ }$ & & \\
\hline Fibre Boat & 4 Unit & $\sqrt{ }$ & & \\
\hline Aluminum Boat & 1 Unit & $\sqrt{ }$ & & \\
\hline Folding Boat & 1 Unit & $\sqrt{ }$ & & \\
\hline Engine Boat & 9 Unit & $\sqrt{ }$ & & \\
\hline Spotlight + Genset & 1 Unit & $\sqrt{ }$ & & \\
\hline Genset & 2 Unit & $\sqrt{ }$ & & \\
\hline Ford Cliff & 1 Unit & $\sqrt{ }$ & & \\
\hline Pushboard & 1 Unit & $\sqrt{ }$ & & \\
\hline Engine Compressors & 1 Unit & $\sqrt{ }$ & & \\
\hline Stretcher & 1 Unit & $\sqrt{ }$ & & \\
\hline Push Stretcher & 1 Unit & $\sqrt{ }$ & & \\
\hline Barrow & 1 Unit & $\sqrt{ }$ & & \\
\hline Megaphone & 1 Unit & $\sqrt{ }$ & & \\
\hline Rope & 2 Unit & $\sqrt{ }$ & & \\
\hline Family Tent & 3 Unit & $\sqrt{ }$ & & \\
\hline Chainsaw & 25 Unit & 17 & & 8 \\
\hline Siren & 20 Unit & $\sqrt{ }$ & & \\
\hline Sound Monitor/Siren & 1 Unit & $\sqrt{ }$ & & \\
\hline Water filter + Genset & 1 Unit & $\sqrt{ }$ & & \\
\hline Floating pump & 3 Unit & $\sqrt{ }$ & & \\
\hline Carabiner and Conectore & 1 Unit & $\sqrt{ }$ & & \\
\hline Scuba Tools & 2 Unit & $\sqrt{ }$ & & \\
\hline Satellite Telephone & 1 Unit & $\sqrt{ }$ & & \\
\hline GPS & 2 Unit & $\sqrt{ }$ & & \\
\hline Pusdaltin & 1 Paket & $\sqrt{ }$ & & \\
\hline
\end{tabular}

\section{Published By:}

Blue Eyes Intelligence Engineering \& 


\section{The Capability of BPBD to Reducing Disaster Risk in Padang City - Indonesia}

\begin{tabular}{llll}
\hline HT & 18 Unit & 15 \\
Radio Equipment & 1 Unit & $\sqrt{ }$ & 3 \\
Antena MF/MW Portable & 1 Unit & $\sqrt{ }$ \\
Telephone / Fax & 1 Unit & $\sqrt{ }$ \\
Radio Rig & 3 Unit & $\sqrt{ }$ \\
Repeater & 1 Unit & $\sqrt{ }$ \\
Iron Container & 1 Unit & $\sqrt{ }$ \\
Office Container & 1 Unit & $\sqrt{ }$ \\
Locker & 1 Unit & $\sqrt{ }$ \\
Iron Cupboard & 2 Unit & $\sqrt{ }$ \\
Iron rack & 2 Unit & $\sqrt{ }$ \\
Drone & 1 Unit & $\sqrt{ }$ \\
Oxygen Generator & 1 Unit & $\sqrt{ }$ \\
\hline
\end{tabular}

Source [12]

From this table, it can be seen that the amount of equipment owned by BPBD Padang is still inadequate and some equipment is in a damaged condition. Some equipment whose numbers are still lacking in BPBD Padang includes platoon tents, family tents, rescue cars, rubber boats, motorbikes, chainsaw, and sirens. This can hamper the BPBD Padang in carrying out disaster management at all stages of the disaster i.e pre-disaster, disaster emergency response, and post-disaster. Indeed, for the time being, Padang City is still faced with relatively small disasters, but to deal with major disasters such as the earthquake and tsunami will certainly make the BPBD Padang overwhelmed and service output becomes not optimal. For this reason, the BPBD Padang must immediately increase the amount of equipment that is currently lacking especially to deal with disasters that have great intensity.

BPBD Padang itself has tried to increase the amount of the lack of facilities and infrastructure owned by submitting letters and reports to the central government and local governments. However, these efforts are still hindered due to a limited budget for disasters so that the number of requests submitted by the BPBD Padang is often not as expected. For this reason, BPBD Padang cooperates with stakeholders involved in disasters to fulfil equipment that are inadequate when a disaster occurs. Besides that, BPBD Padang has carried out maintenance and maintenance on equipment owned by BPBD Padang such as checking sirens which are conducted twice a month, checking inflatable boats, and service for other equipment. This is done to reduce the number of damage to equipment owned by the BPBD Padang so that these tools can be used for a long period.

BPBD Padang also has Digital Video Broadcast (DVB), Fax, and E-mail that is used to receive earthquake information from Meteorology Climatology and Geophysics Agency (BMKG). BPBD Padang also has an Early Warning System (EWS), Handy Talky (HT) radio, and social media to disseminate earthquake and tsunami information received from BMKG to the public. As a rule, BPBD Padang has clear procedures for disseminating information to the public through an early warning system. BPBD Padang has an Standard Operating Procedure (SOP) that regulates how the procedure for entry and exit of information. So the information that is entered must be analyzed first by providing the information to the leadership ranks for decision making until the information can be disseminated through sirens to the public. Then, the BPBD Padang also carried out several programs and activities to reduce the risk of tsunami disaster aimed at the community. In the last 3 years, the
BPBD Padang has carried out programs and socialization activities on disaster mitigation and preparedness aimed at the community in the form of the Padang Kota Disaster Smart and Disaster Smart Family program. But until now, the program that has been running for 3 years has not yet been measured how smart the people of Padang City are knowledgeable about disasters. There is already a discourse for evaluating some of these programs, but until now there has been no discussion about the exact date of the evaluation. For this reason, it is necessary to immediately evaluate the programs and activities that have been carried out by BPBD Padang so that in the future, the programs and activities that will be carried out can be more effective and efficient.

\section{CONCLUSIONS}

The capability of the BPBD Padang in disaster risk reduction in the Padang City seen from the institutional, human, financial, and technical aspects can not be considered good. The institutional capability of BPBD Padang in terms of organizational structure is good enough. This is evident from the clear division of tasks, roles and responsibilities in the BPBD Padang. However, there is still a problem, i.e coordination by the BPBD Padang is not yet optimal due to the sectoral egos of each disaster organization and there are important rules, i.e RPBs that are not yet legal in the Padang City. Therefore, the BPBD Padang needs to improve the coordination function with stakeholders related to disaster so that it helps in overcoming the deficiencies of the BPBD Padang. For the capability of BPBD Padang, human resources are still very lacking. This can be seen from the many positions or positions in BPBD Padang that have not been filled. This is because the recruitment system is constrained by high budget and mutation rates in the BPBD Padang. Besides, the BPBD Padang also rarely carries out activities related to increasing employee capacity. For this reason, $\mathrm{BPBD}$ Padang needs to increase activities in the form of training aimed at capacity building for employees. In the aspect of BPBD Padang financial capability, it is still insufficient. This can be seen from the minimal budget of the BPBD Padang because the government has not prioritized the issue of disaster as a strategic issue so that the budget for hatred becomes minimal and is often cut. Then in the aspect of technical capabilities owned by BPBD Padang also not yet good. For equipment owned by BPBD Padang, it is still lacking in terms of quantity and completeness, so it must be immediately added and equipped to deal with disasters that have great intensity. Besides, the BPBD Padang has not yet evaluated programs and activities aimed at the community in the context of disaster mitigation and preparedness. For this reason, it is hoped that the BPBD Padang will increase the number of studies and evaluations so that in the future programs and activities that will be carried out can run effectively and efficiently so that there is no waste of funds in the BPBD Padang.

Published By:

Blue Eyes Intelligence Engineering \&

Sciences Publication

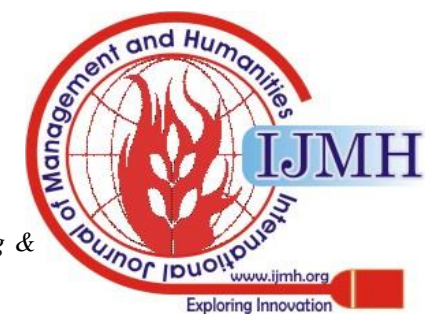




\section{ACKNOWLEDGEMENT}

This research was supported by Universitas Negeri Padang (UNP) and BPBD Padang. We also thank of Rector UNP and Staff, Students involved in research, and Padang City Government-West Sumatra Province for their support in this research.

\section{REFERENCES}

1. C.C. IPCC, The Scientific Basis. Contribution of Working Group I to the Third Assessment Report of the Intergovernmental Panel on Climate Change. Cambridge University Press, United Kingdom, 881. 2001

2. World Economic Forum (WEF), The global risks report 2019, Geneva

3. Wamsler and A. Johannessen, Meeting at the crossroads? Developing national strategies for disaster risk reduction and resilience: Relevance, the scope for, and challenges to, integration. International Journal of Disaster Risk Reduction, 45, 101452. 2020

4. Local Disaster Management Agency (BPBD) Padang, Strategic Plan 2014-2019, 2014

5. Z. Alhadi, K.D. Maani, P. Nurhabibi and A. Syarief, An analysis of the problem in composing of tsunami contingency plan in Padang City. In MATEC Web of Conferences, Vol. 229, p. 03007. 2018

6. K. Haynes and T.M. Tanner, Empowering young people and strengthening resilience: Youth-centred participatory video as a tool for climate change adaptation and disaster risk reduction. Children's Geographies, Vol. 13, Issue. 3, pp. 357-371. 2015

7. Islam, and J. Smart, Challenges in integrating disaster risk reduction and climate change adaptation: Exploring the Bangladesh case. International Journal of Disaster Risk Reduction, 101540, 2020.

8. Maryuhembri, Kapabilitas Pemerintah Daerah Kabupaten Kuantan Singingi dalam Pengelolaan Ruang Terbuka Hijau (RTH) Tahun 2011-2015. JOM FISIP. Vol. 4 Issue. 1. 2006

9. G. Schreyögg and M. Kliesch-Eberl, (2007). How dynamic can organizational capabilities be? Towards a dual-process model of capability dynamization. Strategic management journal, Vol. 28, Issue. 9, pp.913-933, 2007

10. Kusumasari, Manajemen Bencana dan Kapabilitas Pemerintah Lokal. Yogyakarta: Penerbit Gava Media. 2014

11. L.J. Moleong. Metode Penelitian Kualitatif (Edisi Revisi). Bandung: PT Remaja Rosdakarya, 2009

12. Local Disaster Management Agency (BPBD) Padang. Job Analysis Results Report, Workload Analysis and Job Competency Standards for Padang City Disaster Management Agency. 2018

13. A. P. Meiningrum, Kapasitas Pemerintah Kabupaten Pelalawan dalam Pembangunan Kawasan Teknopolitan (Studi Pembangunan Kawasan Pendidikan). JOM FISIP Vol. 4 No. 1. 2017.

\section{AUTHORS PROFILE}

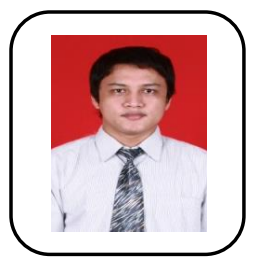

Zikri Alhadi is an Assistant Professor at the Departement of Public Administration, Universitas Negeri Padang. His research focus on administration, public policy, and governance. Besides that his research also focuses on environmental and development studies. He is the Program Manager of The Center For Policy And Social Development Studies and also a team of experts in the preparation of disaster management plans and a number of other expert work in the field of sustainable development. He now serves as Chief of The Bureau Of The Association Of State Administration Scientists (ASIAN) in West Sumatra Province, Indonesia.

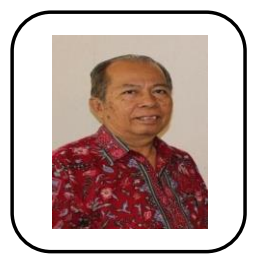

Bustari Muchtar is a Professor in Economics at the Faculty of Economics, Universitas Negeri Padang. His research focuses on Environmental and Development Studies.

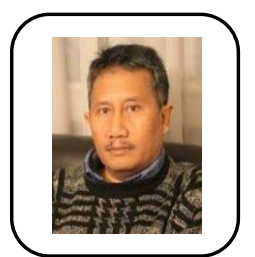

Afriva Khaidir is an Associate Professor in Departement of Public Administration, Universitas Negeri Padang. His research focus on public policy and environmental law. In addition to serving as Vice Dean Of Academic Affairs at the Faculty of Social Sciences, Universitas Negeri Padang, he currently also serves as Chairman Of Association Of State Administration Scientists (ASIAN).

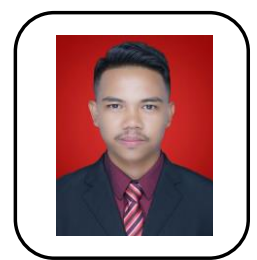

Eko S.V. Turnip is a holder of a Bachelor of Public Administration degree at Universitas Negeri Padang. His research Focus on Administration and Public Policy.

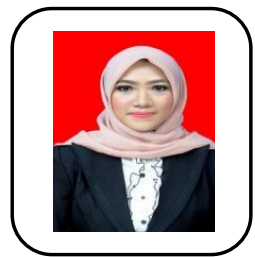

Novia Sari Yanti is a holder of a Bachelor of Public Administration degree at Universitas Negeri Padang. His research Focus on Administration and Public Policy.

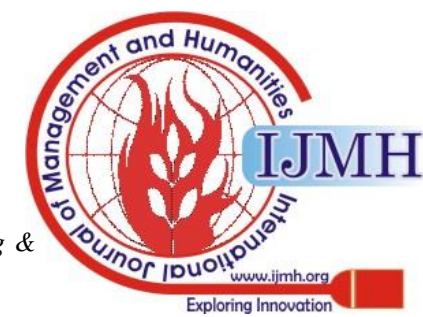

